\title{
Frequency of skin diseases among sea fishermen in Basrah
}

\author{
K Al Hamdi, M Al-Malikey
}

\section{Citation}

K Al Hamdi, M Al-Malikey. Frequency of skin diseases among sea fishermen in Basrah. The Internet Journal of Dermatology. 2008 Volume 7 Number 1.

\section{DOI: $\underline{10.5580 / 16 f 6}$}

\author{
Abstract \\ The sea represents part of the southern border of Basrah. Working in and dealing with the sea water, mainly fishing, is the \\ occupation of many Basrah citizens, where a number of them are attending the out patient clinic of Dermatology and \\ Venereology at the Basrah Teaching Hospital suffering from skin diseases. \\ Objectives: \\ The objectiv of the present work is to evaluate the frequency of skin diseases among sea fishermen in Basrah. \\ Patients and Methods: \\ This is a case-control epidemiological study in which 230 sea fishermen have been collected from the fishing boats harbor (Al- \\ Nagaah) at Al-Fao city during the period between May 2006 through July 2007. \\ All of them were males and their ages were ranging from 12-72 years with a mean \pm SD $28.60 \pm 11.88$. \\ Two hundred thirty subjects attending the outpatient clinic of the general hospital of the same city, as companions of the \\ patients, were enrolled in this study as a control group. They were of comparable age, sex, and season. Fishermen were \\ excluded.
}

Results:

The study showed that marine stings (including jellyfish stings, seabather's eruption, stingray and stonefish stings) were specific for sea fishermen in comparison with control 48 (20.9\%) Vs. 0, the frequency of other skin diseases were higher and achieved a statistical significance among sea fishermen in comparison with control group in the following skin diseases:, bacterial infection 35 (15.2\%) Vs. 9 (3.9\%) , fungal infection 79 (34.3\%) Vs.46 (20\%), warts 25(10.9\%) Vs. 9 (3.9\%), sunburn 35 (15.2\%) Vs. 13 (5.7\%), facial wrinkling 9 (34.3) Vs.52 (22.6\%), lentigens and freckles 36(15.7\%) Vs .15 (6.5\%), contact dermatitis 25(10.9\%) Vs. $7(3 \%)$, palmer hyperkeratosis $130(56.5 \%)$ Vs.43 (18.7\%), miliaria $58(25.2 \%)$ Vs.30 (13\%) respectively.

Some other skin diseases were also higher but did not reach a statistical significance: melasma, actinic chelitis, cutis rhomboidalis nuchae and chilblain; the other skin diseases were not different like cholinergic urticaria, seborrhoeic dermatitis and discoid lupus erythematosus.

Conclusion:

The present work showed that fishing in the sea is a hazardous occupation in which the fishermen are liable for different skin diseases caused by their hard working environment, so that dermatologists working in this area should be familiar with these diseases.

\section{BACKGROUND}

The occupational aspect of dermatology have attracted increasing attention $\left({ }_{1}\right)$. This has been reflected in the establishment, in some countries, of special department of occupational dermatology $\left({ }_{2}\right)$.

Sea represents part of the southern border of Basrah. Working in and dealing with the sea water mainly fishing is the occupation of many Basrah citizens, where number of them are attending the out patient clinic of Dermatology and Venereology at Basrah Teaching Hospital suffering from skin diseases. Fishing in the sea is an outdoor occupation that can be associated with:

1. Frequent and prolonged sun exposure (3).

2. Frequent and prolonged contact with sea water; which is associated with continuous wetness and potential hazards of marine creature. (3) 
3. Exposure to changes in the environmental conditions, especially those regarding extremes of temperature and humidity (3).

4. Contact with the equipment used in the marine work which may be hazardous to the skin as they can cause for e.g. contact dermatitis and traumatic injuries which can be a portal of entry for various infectious agents. (3) So this study was designed to evaluate the frequency of skin diseases among sea fishermen in Basrah as similar Iraqi studies in this field are lacking.

\section{PATIENTS AND METHODS}

This is a case-control epidemiological study in which 230 sea fishermen have been collected from the fishing boats harbor(Al-Nagaah) at Al-Fao city during the period between May 2006 through July 2007.

All of them were males and their ages were ranging from 12-72 years with a mean \pm SD $28.60 \pm 11.88$.

Two hundred thirty subjects attending the outpatient clinic of the general hospital of the same city, as companions of the patients, were enrolled in this study as a control group. They were of comparable age, sex, and season. Fishermen were excluded.

A full history and dermatological examination was carried out to establish the diagnosis of skin diseases on clinical bases in both cases and controls. For the determination of statistical significance among different variables, a descriptive statistics like mean and standard deviation together with analytic statistics like chi squared test, t-test or fischer exact test have been done when appropriate. A pvalue less than 0.05 was considered significant. SPSS version 11 has been used. The consent of all patients was taken prior to their inclusion in this study ,meanwhile, the permission of the local ethical committee to conduct the study was also obtained. .

\section{RESULTS}

The study showed that the frequency of skin diseases were as follows (table 1):

1-skin diseases that were higher and specific to sea fishermen like marine stings which were 48 (20.9\%) Vs. 0 among cases and control groups respectively.

2-skin diseases which were highly significant statistically among sea fishermen in comparison with control group , ( $\mathrm{p}$ value < 0.05): bacterial infection $35(15.2 \%)$ Vs. $9(3.9 \%)$, fungal infection $79(34.3 \%)$ Vs.46 (20\%), warts $25(10.9 \%)$ Vs. 9 (3.9\%), sunburn 35 (15.2\%) Vs. $13(5.7 \%)$, facial wrinkling 79 (34.3) Vs.52(22.6\%), lentigens and freckles $36(15.7 \%)$ Vs .15 (6.5\%), contact dermatitis 25(10.9\%) Vs. 7(3\%), palmer hyperkeratosis 130 (56.5\%) Vs.43 (18.7\%), miliaria 58 (25.2\%) Vs.30 (13\%).

3-Skin diseases which were higher among sea fishermen but did not achieve statistical significance ( $\mathrm{p}$-value $>0.05$ ) like melasma $6.1 \%$ Vs. $2.6 \%$, actinic chelitis $3 \%$ Vs. $0.9 \%$, cutis rhomboidalis nuchae $1.7 \%$ Vs. 0 and chilblain $2.2 \%$ Vs. $0.4 \%$ among cases and control respectively.

4-Skin diseases which were not different between cases and controls like cholinergic urticaria 10 (4.3\%) Vs.13(5.7\%), seborrhoeic dermatitis $8(3.5 \%)$ Vs.7(3\%) and discoid lupus erythematosus $1(0.4 \%)$ Vs.0 respectively.

Frequency of skin diseases caused by marine stings (table 2 ):

The highest number of marine stings was caused by jellyfish $18(7.8 \%)$ followed in order of frequency by seabather's eruption $13(5.7 \%)$, stingray $11(4.8 \%)$ and stone fish $6(2.6 \%)$. All sea fishermen gave history of stings uncountable times during the work. The most common sting encountered were caused by jellyfish, most of which were mild, self limited and manifested by erythema, burning pain and itching at the site of sting which disappeared within few hours; some other cases were manifested by erythematous streaks, wheals and post inflammatory hypopigmentation at the site of sting. The sites affected were mostly the hands, forearms and even the eyes. Regarding seabather's eruption $13(5.7 \%)$ cases have been registered, all of them gave history of swimming in the sea few hours before the development of maculopapular and vesicular eruption at the sites covered by clothes.

Stingray stings were the most painful sting, 11(4.8\%) cases were found and presented as a puncture wound at the site of sting .

A six cases $(2.6 \%)$ of stone fish stings has been reported which happened during cleaning of the net by the fishermen , they were painful and left a puncture wound.

Frequency of skin diseases caused by infections (table 3): When we classified and compared diseases caused by 
infections between cases and controls the following skin diseases showed a significant statistical difference ( $\mathrm{p}$ value $<$ $0.05)$ : bacterial folliculitis $21(9.1 \%)$ Vs. 6(2.6\%), boils 11 $(4.8 \%)$ Vs. 3 (1.3\%), Pityriasis versicolor 37(16.1\%) Vs. $17(7.4 \%)$, warts $25(10.9 \%)$ Vs. 9(3.9\%) respectively. The other diseases like cellulitis, toe and finger webs fungal infections, pityrosporum folliculitis , onychomycosis, tinea cruris and tinea corporis were higher among sea fishermen but did not achieve statistical significance.

\section{Figure 1}

Table 1 :Frequency of skin diseases among cases and controls

\begin{tabular}{|l|c|c|c|c|c|}
\hline Skin diseases & $\begin{array}{l}\text { Case } \\
(\mathrm{n}=230)\end{array}$ & $\%$ & $\begin{array}{l}\text { Control } \\
(\mathrm{n}=230)\end{array}$ & $\%$ & p-value \\
\hline $\begin{array}{l}\text { bacterial } \\
\text { infection }\end{array}$ & 35 & 15.2 & 9 & 3.9 & 0.001 \\
\hline $\begin{array}{l}\text { fungal } \\
\text { infection }\end{array}$ & 79 & 34.3 & 46 & 20 & 0.001 \\
\hline Wauts & 25 & 10.9 & 9 & 3.9 & 0.007 \\
\hline Sunbum & 35 & 15.2 & 13 & 5.7 & 0.001 \\
\hline Facial wrinkling & 79 & 34.3 & 52 & 22.6 & 0.007 \\
\hline $\begin{array}{l}\text { Lentigens and } \\
\text { freckles }\end{array}$ & 36 & 15.7 & 15 & 6.5 & 0.003 \\
\hline Melasma & 14 & 6.1 & 6 & 2.6 & 0.1 \\
\hline Actinic chelitis & 7 & 3 & 2 & 0.9 & 0.17 \\
\hline
\end{tabular}

\section{Figure 2}

Table2:Frequency distribution of marine stings among sea fishermen

\begin{tabular}{|l|l|l|}
\hline & $\begin{array}{l}\text { Cases } \\
(\mathbf{n}=230)\end{array}$ & $\%$ \\
\hline Jellyfish stings & 18 & 7.8 \\
\hline $\begin{array}{l}\text { Seabather's } \\
\text { eruption }\end{array}$ & 13 & 5.7 \\
\hline Stingray stings & 11 & 4.8 \\
\hline Stonefish stings & 6 & 2.6 \\
\hline None & 182 & 79.1 \\
\hline Total & 230 & $100 \%$ \\
\hline
\end{tabular}

\section{Figure 3}

Table 3:Frequency distribution of skin diseases due to infection among cases and controls

\begin{tabular}{|c|c|c|c|c|c|}
\hline & $\begin{array}{l}\text { Cases } \\
\mathbf{n}=230\end{array}$ & $\%$ & $\begin{array}{l}\begin{array}{l}\text { Control } \\
\mathbf{n}=230\end{array} \\
\end{array}$ & $\%$ & p-value- \\
\hline $\begin{array}{l}\text { Bacterial } \\
\text { folliculitis }\end{array}$ & 21 & 9.1 & 6 & 2.6 & 0.003 \\
\hline Boils & 11 & 4.8 & 3 & 1.3 & 0.03 \\
\hline Cellulitis & 3 & 1.3 & - & - & $\begin{array}{l}\text { Not } \\
\text { done }\end{array}$ \\
\hline $\begin{array}{l}\text { Pityriasis } \\
\text { versicolor }\end{array}$ & 37 & 16.1 & 17 & 7.4 & 0.004 \\
\hline $\begin{array}{l}\text { Toe and finger } \\
\text { webs fungal } \\
\text { infection }\end{array}$ & 19 & 8.3 & 17 & 7.4 & 0.72 \\
\hline $\begin{array}{l}\text { Pityrosponum } \\
\text { folliculitis }\end{array}$ & 10 & 4.3 & 8 & 3.5 & 0.63 \\
\hline onychomycosis & 5 & 2.2 & - & - & $\begin{array}{l}\text { Not } \\
\text { done }\end{array}$ \\
\hline Tinea cruris & 7 & 3 & 4 & 1.7 & 0.36 \\
\hline Tinea corporis & 1 & 0.4 & - & & $\begin{array}{l}\text { Not } \\
\text { done }\end{array}$ \\
\hline Warts & 25 & 10.9 & 9 & 3.9 & 0.004 \\
\hline
\end{tabular}

\section{Figure 4}

Figure 1: Seabather's eruption

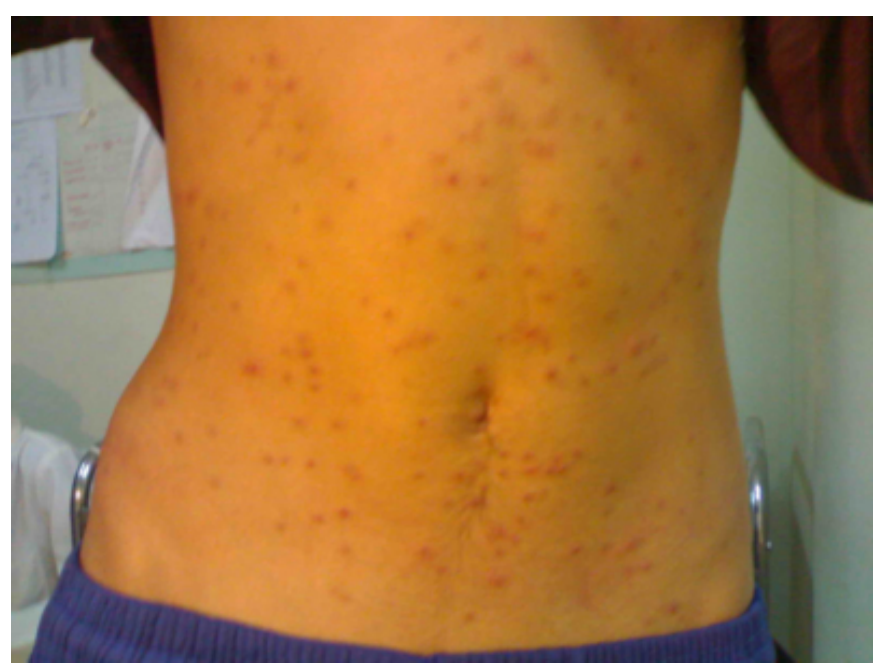

\section{DISCUSSION}

Sea fishermen are heavy outdoor workers and are exposed to different hazards which can be acquired from the sea for example jellyfish stings or from the change in the environmental factors like intense prolonged sun exposure and extremes of temperature and humidity or other factors related to marine environment.

\section{MARINE STINGS}

The study showed that marine stings were very common among sea fishermen, all of them gave history of stings uncountable times during the work. The most common encountered stings were caused by jellyfish followed in order of frequency by seabather's eruption, stingray sting and 
stonefish sting and this is related to their direct contact with these stinging creature.

\section{BACTERIAL INFECTION}

Fishermen are prone to infection especially of the hands and fingers because of their working environment, where they are subjected to repeated trauma caused by handling fish and the equipment used for fishing $\left(_{3}\right)$ together with the hot humid dirty environment $\left({ }_{5}\right)$.

\section{FUNGAL INFECTION}

The increased frequency of fungal infection can be explained by the high humidity, high temperature $\left({ }_{4}\right)$ together with continuous wetness and profuse perspiration(3).

\section{HAZARDS OF SOLAR RADIATION}

In this study we found an increase in the skin diseases related to sun exposure and this proved the effect of chronic cumulative sun exposure. No cutaneous malignancy have been detected in our study and this can be attributed to the dark complexion of the majority of the studied $\operatorname{group}\left({ }_{6}\right)$.

\section{CONCLUSION}

The present work showed that fishing in the sea is a hazardous occupation in which the fishermen are liable for different skin diseases caused by their hard working environment, so that dermatologists working in this area should be familiar with these diseases.

\section{CORRESPONDENCE TO}

Ass.Prof. Khalil I ALHamdi Department of Dermatology and Venereology, College of Medicine, University of Basrah. Email: drmoh42000@yahoo.com Mobile No. 09647801405354

\section{References}

1. J.S.C. English. Occupational dermatoses, In: Tony Burns, Stephen Breathnach, Neil Cox, Christopher Griffiths. Rook's Text book of Dermatology ,7th Ed London; Blackwell Ltd; 2004, (1) 21:21.1.

2. Calnan CD, Rycroft RJG. Rehabilitation in occupational skin disease. Trans Coll Med S Afr 1981; 25 (Supplement on Third Interdisciplinary Symposium: Rehabilitation): 136-42. 3. William A. Burke; skin problems related to the occupation of commercial fishing in North Carolina. NC Med J July/August 2006, 67, (4): 7.

4. Faergemann J: Pityrosporum infections. J Am. Acad. Dermatol 1994, 31: 518.

5. Robert M. Adams; Occupational skin disease in: Irwin M.Freedberg, Arthur Z. Eisen, Klans Wolff, K. Frank Austen, Lowell A. Gold Smith, Stephen I. Katz. Fitz Patrick's, Dermatology In General Medicine 6th edition; Mc Graw Hill. Philadelphia, 2003, 137: 1315.

6. Coldiron BM: Thinning of the ozone layer: Facts and consequences. J Am Acad Dermatol 1992; 27: 653, PubMed MUID 1430383. 


\section{Author Information}

Khalil I. Al Hamdi, MD; Ph.D

Assistant Prof. ,Consultant Dermatologist, HOD, Department of Dermatology and Venereology, College of Medicine, University of Basrah

Mohsin A. Al-Malikey, MD; FICMS

Basrah Teaching Hospital 